\title{
Field practice internship final report
}

May 1994

Oak Ridge National Lab., TN (United States)

Reproduced and Distributed by:

U.S. DEPARTMENT OF ENERGY

Office of Scientific and Technical Information

P.O. Box 62

Oak Ridge, TN 37831 


\section{DISCLAIMER}

This report was prepared as an account of work sponsored by an agency of the United States Government. Neither the United States Government nor any agency thereof, nor any of their employees, make any warranty, express or implied, or assumes any legal liability or responsibility for the accuracy, completeness, or usefulness of any information, apparatus, product, or process disclosed, or represents that its use would not infringe privately owned rights. Reference herein to any specific commercial product, process, or service by trade name, trademark, manufacturer, or otherwise does not necessarily constitute or imply its endorsement, recommendation, or favoring by the United States Government or any agency thereof. The views and opinions of authors expressed herein do not necessarily state or reflect those of the United States Government or any agency thereof. 


\section{DISCLAIMER}

Portions of this document may be illegible in electronic image products. Images are produced from the best available original document. 
MASTERS IN PUBLIC HEALTH

THE UNIVERSITY OF TENNESSEE, RNOXVIILE

FIELD PRACTICE INTERNSHIP FINAL REPORT

by

TAMMIE FOSTER

May 2, 1994 
TABLE OF CONTENTS

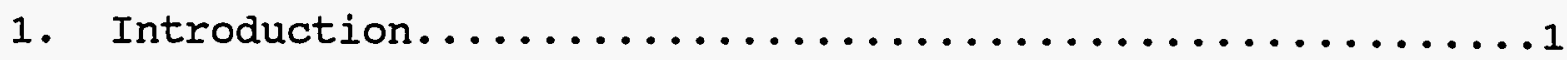

2. Martin Marietta Energy systems, Inc.................

3. Martin Marietta Energy Systems Environmental Management

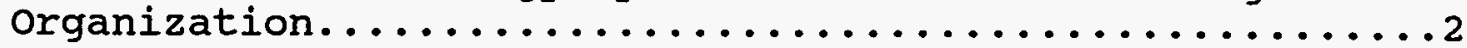

4. Superfund Amendments and Reauthorization Act (SARA), Title III Emergency Planning and Community Right-to-know

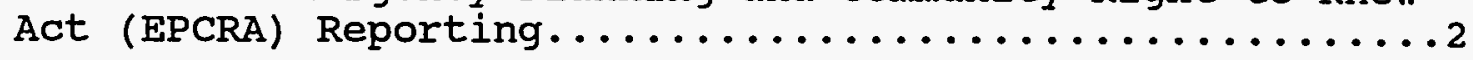

5. Benefits of Field Practice...................6

6. References.............................

7. Attachment 1 - List of Hazardous substances subject to Inventory for Calendar Year 1993.................

8. Attachment 2 - Exemptions for Inventory Reporting......12

9. Attachment 3 - Instructions for Completing the Hazardous

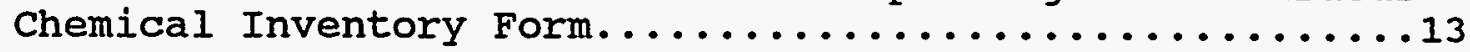

10. Attachment 4 - Hazardous Chemical Summary Form........16

11. Attachment 5 - Superfund Amendments and Reauthorization Act, Title III Emergency Planning and Community Right-to-know, Tier II Report..................... 


\section{Introduction}

This field practice internship final report gives an overview of the field practice, which was completed at the Oak Ridge Y-12 Plant, Martin Marietta Energy systems, Inc., Environmental Management Department, Oak Ridge, Tennessee. The field practice focused on the completion of the superfund Amendments and Reauthorization Act (SARA) Title III, Emergency Planning and Community Right-to-know Act section 312, Tier II Report. The field practice internship was conducted on a fulltime basis between December 13, 1993 through February 18, 1994. Sheila Poligone, Emergency Planning and Community Right-to-know Act (EPCRA) Coordinator served as the field practice preceptor.

\section{MARTIN MARIETTA ENERGY SYSTEMS ORGANIZATION}

The Oak Ridge $\mathrm{Y}-12$ Plant is one of three installations managed by Martin Marietta Energy Systems (MMES), for the United states Department of Energy (USDOE). The other installations include the Oak Ridge National Laboratory (ORNL) and the K-25 site. MMES is dedicated to the ethical and efficient operation of these installations and is committed to policies that promote safe operations and the health and job satisfaction of all 
employees.1 MMES facilities are involved in the "research and development of safe, economic, environmentally acceptable technologies for the efficient production and use of energy. ${ }^{2}$

\section{Martin Marietta Energy Systems} Environmental Management Department

The Environmental Management Department develops and implements programs to help protect the environment in the $\mathrm{Y}-12$ valley (including ORNL activities at $\mathrm{Y}-12$ ) and assuring compliance within all applicable federal, state, and local environmental regulations. The program deals with proper management of effluent and wastes resulting from current plant operations and supports remediation of unacceptable environmental conditions that resulted from practices of the past.

SUPERFUND - AMENDMENTS AND REAUTHORIZATION ACT (SARA), TITLE III, EMERGENCY PLANNING AND COMMUNITY RIGHT-TO-RNOW (EPCRA) BECTION 312, TIER II REPORTING

On December 4, 1984, a cloud of methyl isocyanate gas, an extremely toxic chemical, escaped from a Union carbide chemical plant in Bhopal, India. More than 2,500 people lost their lives. Tens of thousands more were injured, some suffering permanent disabilities. Shortly after this accident, a chemical release in West Virginia, though not nearly as serious as Bhopal, encouraged states to pass laws giving workers and citizens access to information about hazardous substances in their workplaces and 
communities. ${ }^{3}$ Even though state laws differ, most require reporting of toxic chemical releases and the presence of hazardous substances.

With the states efforts in mind, in November 1986, Congress passed a law under the Superfund Amendments and Reauthorization Act (SARA) Title III called the Emergency Planning and community Right-to-know Act. This law was designed to assist America's communities in dealing safely and effectively with the many hazardous substances that are used throughout our society. This law consist of two main purposes: to encourage and support emergency planning for responding to chemical accidents; and to provide local governments and the public with information about possible chemical hazards in their communities.

The Code of Federal Regulations, Title 40, Part 370 Hazardous- Chemical Reporting consist of guidelines used for reporting. Community Right-to-know established reporting requirements which provide the public with important information on the hazardous chemicals in their communities for the purpose of enhancing community awareness of chemical hazards and facilitating development of state and local emergency response plans. Hazardous chemicals are defined under 29 CFR 1910.1200(C) as "any chemical which is a physical hazard or a health hazard". Also a chemical is defined to be any element, chemical compound, or mixture of elements and/or compounds. 
The Oak Ridge Y-12 Plant must complete the section 312 report because it is a facility that is required to prepare or have available a Material Safety Data Sheet (MSDS) for a hazardous chemical under the Occupational safety and Health Act of 1970 and regulations promulgated under that Act. The section 312 report provides various agencies and local fire departments with additional data on hazardous chemicals by requiring an annual submission of inventory and storage information from reporting facilities. The provisions of section 312 also apply to mixtures of hazardous chemicals. Facilities are given the option of providing report data on each component in the mixture that is a hazardous chemical. However, data on the mixture can be reported as long as the MSDS and inventory reporting of mixtures "where practicable" is consistent for both types of reporting. If a facility chooses the component method of mixture reporting, then the concentration of the hazardous chemical, in weight percent mass (greater than 1 percent or 0.1 percent if carcinogenic) must be multiplied by the mass (in pounds) of the mixture to determine the quantity of the hazardous chemical therein. Where the facility chooses to report on the mixture, then the total quantity of the mixture must be reported. The inventory is documented on the Tier II Report. This report provides chemicalspecific information and required data for individual hazardous 
chemicals. Specific data required for the Tier II Report include:

1. The chemical or common name of the hazardous chemical as given on the Material Safety Data Sheet.

2. An estimate, expressed as a range, of the greatest amount of the substance present at the facility during the preceding calendar year.

3. An estimate, expressed as a range, of the average daily amount of the substance present during the preceding calendar year.

4. A brief description of the manner in which the substance is stored.

5. The location of the substance at the facility.

6. Whether the owner or operator wishes to have the storage information withheld from public disclosure. ${ }^{3}$

All hazardous chemicals which are procured through stores, Accelerated Vendor Inventory Delivery (AVID), and Direct Charge are reviewed for a calendar year (CY). From this review, a list of hazardous chemicals are compiled which could potentially reach/exceed the reporting threshold set by the regulations for hazardous chemicals is 10,000 pounds, and for extremely hazardous substances 500 pounds or the threshold planning quantity, whichever is lower. This list along with a list of Exemptions for Inventory Reporting and instructions for completing the Hazardous Chemical Inventory Form, is then sent to plant personnel to take an inventory of average and maximum daily 
quantities that were stored during the calendar year. Workshops were also setup to assist the individuals in completing the inventory packages correctly.

Information sent in from the plant areas are then compiled on the Hazardous Chemical summary sheets. Compilation of the Hazardous Chemical Summary sheets consist of calculating conversions of weights for chemicals and transferring the information from the Hazardous Material Inventory forms to the Hazardous Chemical summary form for preparation of the Tier II, Section 312 Report. After completion of the Tier II Report, a Quality Assurance/Quality Control ( $Q A / Q C$ ) checklist is completed to ensure that all information is accurate on the form. It is reviewed internally and then submitted to the appropriate regulatory agencies. These agencies includes the Tennessee Emergency Management council (TEMA), the Oak Ridge Fire Department, Anderson, Knox, Roane and Loudon Counties Local Emergency Planning Commissions. It is also submitted to the $\mathrm{Y}-12$ Fire Department personnel.

\section{BENEFITS OF FIELD PRACTICE}

Benefits of my field practice consist of:

1. Awareness of hazardous chemicals stored at MMES and how each toxic and extremely hazardous chemicals are inventoried each calendar year.

2. Being able to follow the process through with the SARA Title III, Section 312 Report from start to finish. 
3. Working directly with the employees submitting the inventories to assist in making sure correct data is being submitted.

4. The interaction of Industrial Hygiene and Environmental Management and how the two disciplines work together to decide the physical and health hazards of all toxic and extremely hazardous chemicals.

5. Developed an understanding of the SARA Title III, EPCRA reporting.

6. Seeing how the various chemicals are stored at MMES and how it effects the surrounding communities.

Also being aware of the emergency response used by MMES in the event of an accidental release.

This experience would be valuable to anyone in the Occupational and Environmental Health and Safety field because it allows contact with employees and exposes them to many aspects of hazardous chemical reporting. This learning experience is very valuable and has helped me to understand the interaction between Industrial Hygiene, Environmental Management, and the surrounding counties as they relate to emergency response. 


\section{REFERENCES}

1. Document cited has not been reviewed for public release.

2. Document cited has not been reviewed for public release.

3. Emergency Planning and Community Right-to-know Handbook, Fourth Edition, J. Gordon Arbuckel, Timothy A. Vanderver, Jr., Paul A. J. Wilson, January 1992, Government Institutes, Rockville, Maryland. 


\section{ATTACHEMENT 1}

\section{LIST OF HAZARDOUS SUBSTANCES \\ SUBJECT TO INVENTORY \\ FOR CY 1993}

A. P. Green Castable Refractory (72-88\% Alumina)

Acetonitrile

Acetone

Acetic Acid

Aluminum Hydroxide

Aluminum Nitrate

Aluminum Oxide

American Limestone Co. Limestone (1-95\% Calcium Carbonate)

Ammonia

Ammonium Hydroxide

Argon

Asphalt

Battery Acid

Beryllium and Beryllium Compounds (excluding parts)

Biogenic SE 377C (<30\% D-Limonene)

Calcium Carbonate

Calcium Chloride

Calcium Hydroxide

Carbon Dioxide

Chlorine

Clear Plastisol (33-46\% Di-sec-octyl Phthalate)

Cutting Coolants

Diatomaceous Earth

Di(2-ethylhexyl) Phthalate

Diphenyimethane diioscyanate

Dixie Portiand \& Masonry Cement

Endcor 4529 ( $<52 \%$ Sulfuric Acid)

Enplate

Ethylene Glycoi

Ethylenediamine 


\section{LIST OF HAZARDOUS SUBSTANCES \\ SUBJECT TO INVENTORY \\ FOR CY 1993 (Cont.)}

Fern-Floc (48.7\% Ferric Sulfate)

Flexible Products (e.g., FP 234-2.5 A-Side. and B-Side)

Foam Components (e.g., Autoflex Polyurethane Component A. and Component B)

Freon 11

Freon 12

Freon 22

Freon 113

Freon 114

Fullers Earth

Gasoline (please distinguish type:

diesel, unieaded, ethanol fuel. kerosene, etc.)

Halons

Helium

Holden Eutectic Mixture 94-18-8

Hydrochloric Acid and HCL Solutions

Hydrofluoric Acid

Hydrogen

Hydrogen Peroxide Solution

Integrated chemistries PCB Extraction System

Johnson Complete for Floors

Johnson Finish JX-4000/Concrete Seaier

Kathene Solution (35-40\% Lithium Chloride)

Kerosene

Lead Metal (e.g., lead bullets)

Lithium Chloride

Lithium Hydroxide

Mercury

Methanol

Methyl Chloroform

Methylene Chloride

Moltan Safety Absorbent 


\section{LIST OF HAZARDOUS SUBSTANCES \\ SUBJECT TO INVENTORY \\ FOR CY 1993 (Cont.)}

Naphtha

Nickel Metal and Nickel Soluble Compounds

Nitric Acid

Nitrogen

Nitrogen Dioxide

Oils (please distinguish type:

petroleum oils, hydraulic, naphtha. etc.)

Oxygen

Perchloroethylene

Plastisol

P-10 Nuclear Counter Mixture (90\% Argon/10\% Methane)

PBS Chemical Co. Sodium Hydrogen Sulfite (15-43\% Sodium Bisulfite)

Potassium Chloride

Potassium Hydroxide

Quickrete Concrete Mix

Quickrete Mortar Mix

Roof Top Liquid, Cement, or Coating (Asphalt)

Sodium Bisulfite

Sodium Carbonate

Sodium Chloride

Sodium Hydroxide and Sodium Hydroxide Solutions

- Sodium Hypochlorite Solutions

Sodium Nitrate

Sodium Phosphate, tribasic, dodecahydrate

Sulfuric Acid

1,1,1-Trichloroethane

2,4-Toluene diisioscynate 


\section{ATTACHMENT 2}

\section{EXEMPTIONS FROM INVENTORY REPORTLNG}

The inventory should be conducted on all hazardous chemicals as defined under $29 \mathrm{CFR}$ 1910.1200 (c), which states that a "hazardous chemical means any chemical which is a physical hazard or a health hazard." A chemical is defined to be "any element. chemical compound, or mixture of elements and/or compounds." There are, however. exemptions cited under the Emergency Planning and Community Right-to-Know Act as defined below. Please consider these exemptions when completing your inventory forms and indicate in the comment section which exemptions you have applied.

1. Any food, food additive, color additive, drug, or cosmetic regulated by the Food and Drug Administration.

2. Any substance present as a solid in any manufactured item to the extent exposure to the substance does not occur under normal conditions of use. Clarification: This would exclude hazardous chemicals in the form of stable, finished parts.

3. Any substance to the extent it is used for personal, family, or household purposes, or is present in the same form and concentration as a product packaged for distribution and use by the general public. Clarification: This would exclude aerosol or spray cans from reporting. Also, a can of paint or a can of motor oil would be excluded. Anything that is in consumer form and not on a bulk scale would be excluded from reporting.

4. Any substance to the extent it is used in a research laboratory or a hospital or other medical facility under the direct supervision of a technically qualified individual. Clarification: Research laboratories and quality control laboratories located within manufacturing facilities are not required to report hazardous chemicals where small amounts of many types of chemicals are used, or stored for short periods, that are not hazardous to the general public when administered or used under appropriate supervision. This does not include pilot scale operations that resemble operations within the plant. Also, if hazardous substances are used for medical purposes they are exempt from reporting requirements.

5. Any substance to the extent it is used in routine agricultural operations or is a fertilizer held for sale by a retailer to the uitimate customer. Clarification: This would exciude the reporting of fertilizers, pesticides, and other chemical substances when applied, administered, or otherwise used as part of routine agricultural activities.

6. Resource Conservation and Recovery Act (RCRA) wastes are not subject to inventory reporting. However, certain RCRA waste information is gathered at a later date for release reporting (i.e., waste shipments off site).

7. Radioactive substances are not subject to reporting. 


\section{ATTACHMENT 3}

\section{INSTRUCTIONS FOR COMPLETING THE HAZARDOUS CHEMICAL INVENTORY FORM}

Please complete all columns to prevent delays in manipulating the data to fulfill the requirements of the Emergency Planning and Community Right-to-Know Act (EPCRA). The following instructions apply toward each hazardous chemical present in your area that is on the List of Hazardous Substances Subject to Reporting for CY 1993 (whether designated as a hazardous chemical or a mixture containing a hazardous chemical component). The form may be completed by hand writing the information, but please ensure that it is readable.

Division: Please provide the organization (i.e., division) name from which you are reporting, do not use numerical numbers.

Area Contact, Phone Number, and Plant Address: Please specify the hazardous communication coordinator for the area or the responsible supervisor/individual.

Chemical Name: Please specify the hazardous chemical present by indicating the hazardous chemical name. If the chemical is a trade name, please supply hazardous constituent and concentration of that constituent (e.g., [P-10 Nuclear Counter Mixture/90\% Argon and 10\% Methane] or [Kathene Solution/35-40\% Lithium Chloride]). Also, if the chemical is a solution or acid, please give concentration of solution (e.g., Nitric Acid - 95\%).

Chemical State: Indicate if the state of the chemical is pure or part of a mixture and what form: solid/liquid/gas.

Stores/Avid Number: If you supply usage, container type, and size, this information is not needed. If for some reason you cannot supply these items, you must supply Stores catalog number.

Buyer's Name and Badge Number: This information can be manipulated with the usage information as a last resort in determining the amount of chemical utilized within the calendar year. It is preferred that you keep records of your chemical usage rather than assume that all chemicals purchased were used during the year. This assumption can lead to 'false high' emission numbers for the plant. If we must rely on the purchase information for the chemical usage information, please be certain that you supply the Stores/Avid Number.

Storage Location: Specify building number and room number (or some sort of area designation or floor if room numbers are unavailable). Also, please give building numbers, not building names. 


\section{INSTRUCTIONS FOR COMPLETING THE HAZARDOUS CHEMIICAL INVENTORY FORM (Cont.)}

Container Type: Specify container type as well as container size. Please specify the unit and size (i.e., 5 gallon. 2.5 liter. $30 \mathrm{lb}$ drum. 1 pint, etc.). Some possible container types are as follows:
Above ground tank
Cardboard/wood box
Below ground tank
Gas/Liquid cylinder
Tank inside building
Steel drum
Plastic or non-metallic drum
Glass bottle or jug
Metal can
Plastic bottle or jug
Plastic carboy
Shatterproof jug
Silo
Tote bin
Bucket
Tank wagon
Fiber drum
Rail car
Paper/plastic bag

Storage Temperature: Please indicate the temperature at which the hazardous chemical is being stored. Possible temperatures are as follows:

Ambient temperature (AT)

Greater than ambient temperature (GAT)

Less than ambient temperature but not cryogenic (LAT)

Cryogenic conditions ( $\mathrm{Cry})$

Storage Pressure: Please indicate the pressure at which the hazardous chemical is being stored. Possible pressures are as follows:
Ambient pressure (AP)
Greater than ambient pressure (GAP)
Less than ambient pressure (LAP)

Average Daily Inventory: For each hazardous chemical, estimate the average daily amount stored in your area during the calendar year 1993. Be sure to specify units.

Maximum Daily Inventory: For each hazardous chemical, estimate the maximum amount stored for any given day during the calendar year 1993. Be sure to specify units.

Usage Location: Specify usage location of the hazardous chemical. If the usage location is the same as storage location, you may enter "same" in the usage location column. 


\section{INSTRUCTIONS FOR COMPLETING THE HAZARDOUS CHEMICAL INVENTORY FORM (Cont.)}

Manner of Usage: Specify how the hazardous chemical is being utilized. This iniormation is very important in determining what thresholds apply for the hazardous chemical specified. Please supply a short descriptive phrase (i.e., plating operations, degreasing process. reagent, etc.).

Usage per year: Specify how much of each hazardous chemical was utilized during calendar year 1993. If you stored, but have not used, the chemical in the last year enter " 0 " in the usage column. If you have discontinued the use of a chemical or made a substitution, please enter "discount." or "sub." in the usage column and supply. the date of the discontinued usage/substitution and disposition of any stock on hand (i.e., surplused or given to another process area) in the comments section on the reverse of the form.

Signature, Date, and Phone Number: Please sign, date. and provide your phone number as a way of certifying that the information is complete.

Additional Information: On the reverse side of the form, please provide any additional comments that might complete your inventory (i.e., changes in production rate or suspension of production for prolonged periods, chemical substitutions, shut down of a process, or surplus of chemical stock/giveaway to another area). 
CHEMICAL NAME:

THRESHOLD QTY:

CONVERSIONS:
CAS NO:

EXHAZ: ( ) Yes ( )No

TOXIC CHEMICAL: ( ) Yes ( ) No

\begin{tabular}{|c|c|c|c|c|c|c|c|c|c|}
\hline $\begin{array}{l}\text { AREA CONTACT \& } \\
\text { ORGANIZATION }\end{array}$ & $\begin{array}{l}\text { CHEMICAL } \\
\text { STATE }\end{array}$ & $\begin{array}{l}\text { STORAGE } \\
\text { LOCATION }\end{array}$ & $\begin{array}{l}\text { CONTAINER } \\
\text { TYPE }\end{array}$ & $\begin{array}{l}\text { TEMP/ } \\
\text { PRESSURE }\end{array}$ & AVG. DAILY & MAX DAILY & $\begin{array}{l}\text { USAGE } \\
\text { LOCATION }\end{array}$ & $\begin{array}{l}\begin{array}{l}\text { MANNER OF } \\
\text { USAGE }\end{array} \\
\end{array}$ & USAGE/YEAR \\
\hline & & & & & & & & & \\
\hline & & & & & & & & & \\
\hline & & & & & & & & & \\
\hline & & & & & & & & & \\
\hline & & & & & & & & & \\
\hline & & & & & & & & & \\
\hline & & & & & & & & & \\
\hline & & & & & & & & & \\
\hline & & & & & & & & & \\
\hline TOTALS & & & & & & & & & \\
\hline
\end{tabular}


ATTACHMENT 5

Y/TS-1173

SUPERFUND AMENDMENTS AND REAUTHORIZATION

ACT (SARA) TITLE III

EMERGENCY PLANNING AND COMMUNITY

RIGHT-TO-KNOH ACT

SECTION 312, TIER TWO REPORT FORMS

R. A. Evans

T. T. Foster

S. E. Poligone

Environmental Management Department Health, Safety, Environment, and Accountability Organization

February 1994

\footnotetext{
Prepared by the

0ak Ridge Y-12 Plant

Oak Ridge, Tennessee 37831

managed by

Martin Marietta Energy Systems, Inc. for the U.S. Department of Energy under Contract DE-ACO5-840R21400
} 


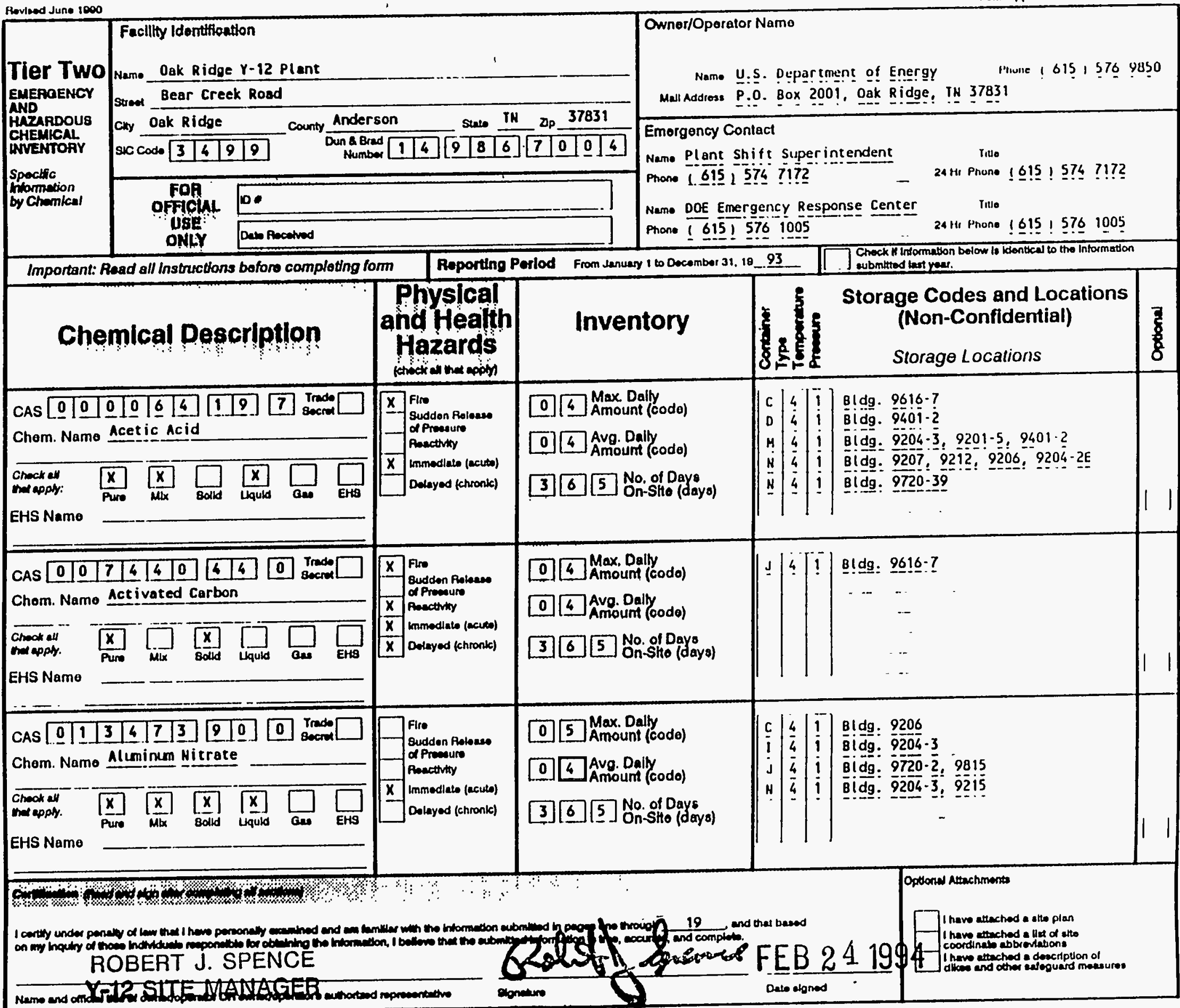


Pave 2 at 19 proges

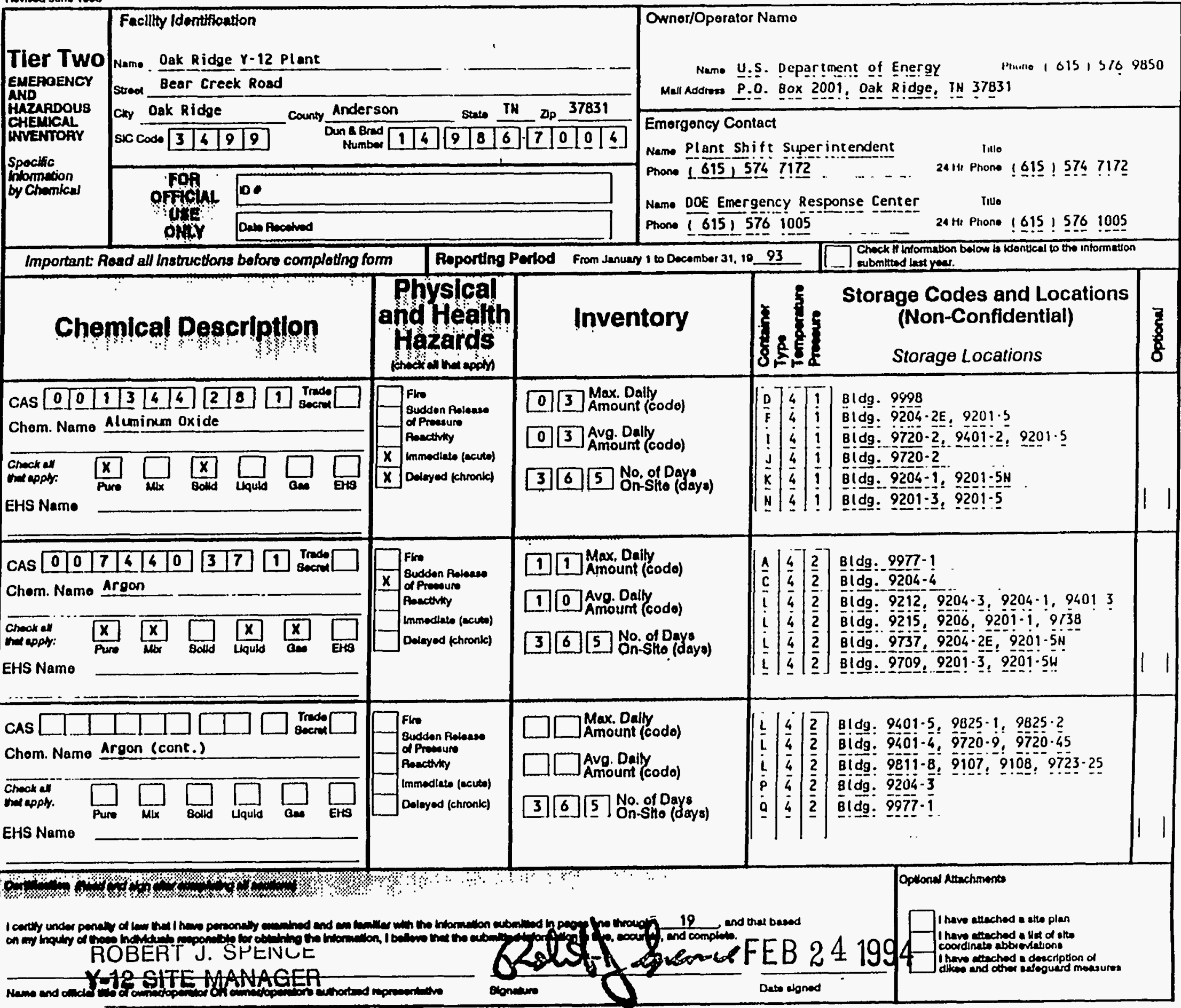




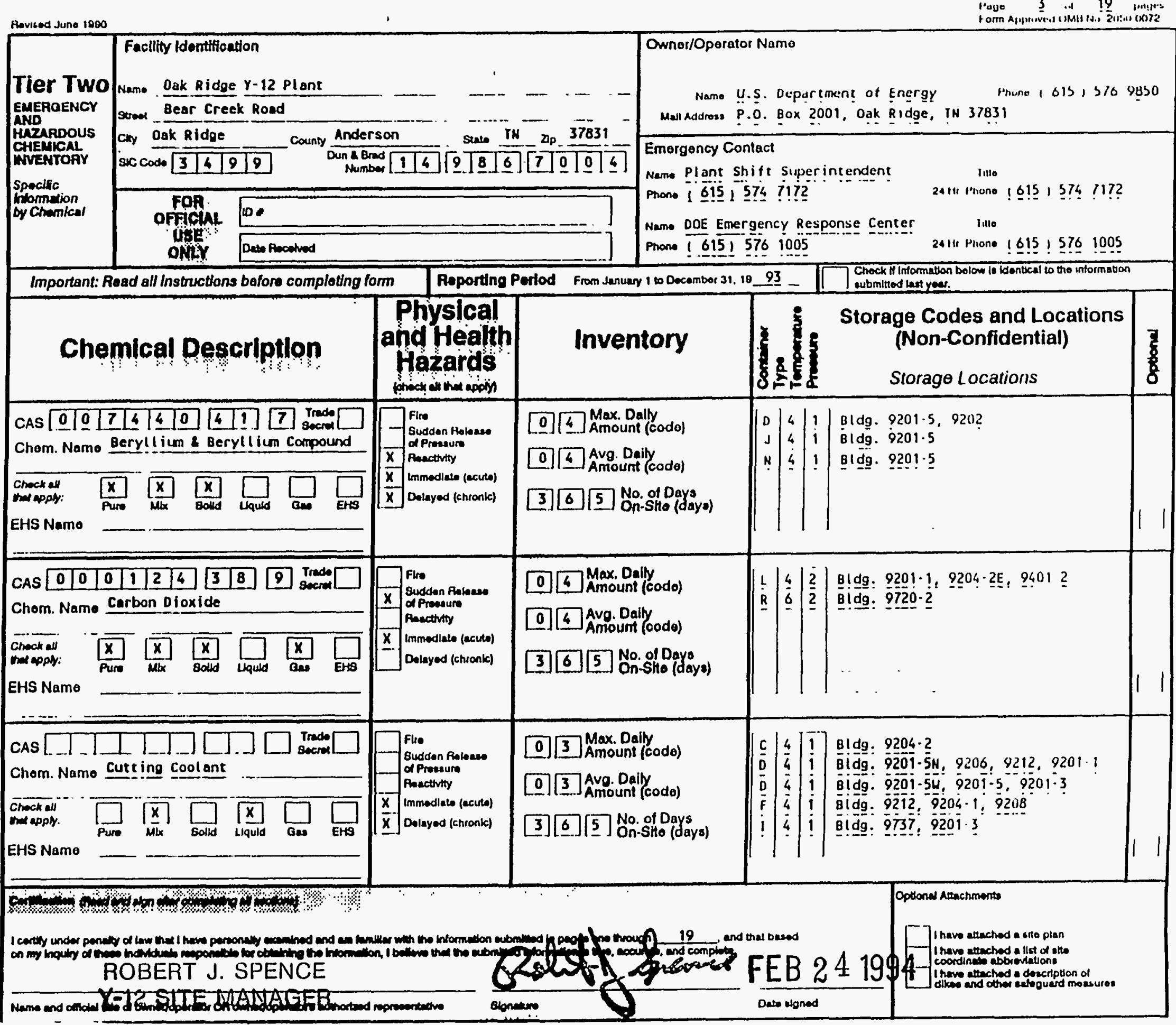




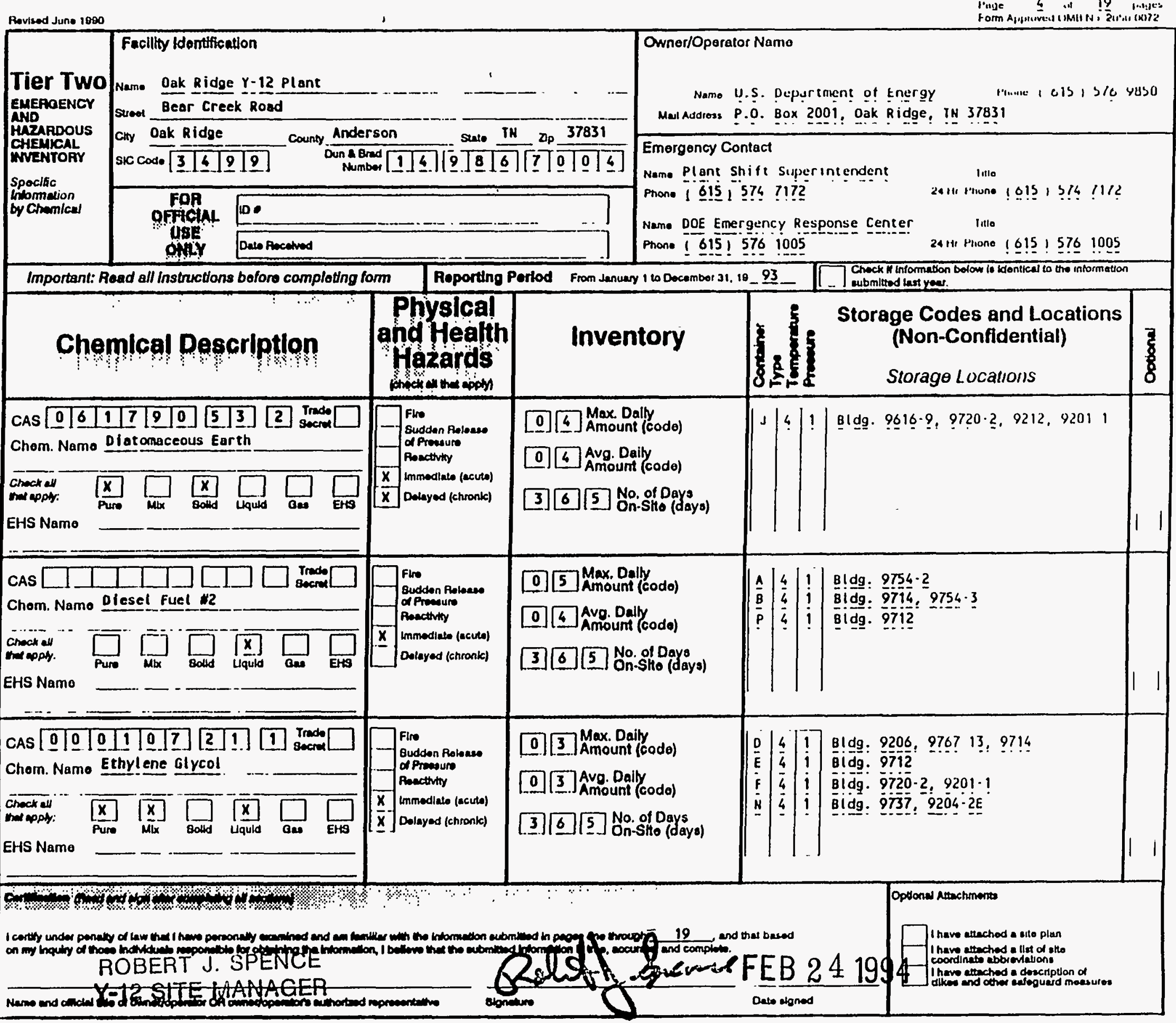




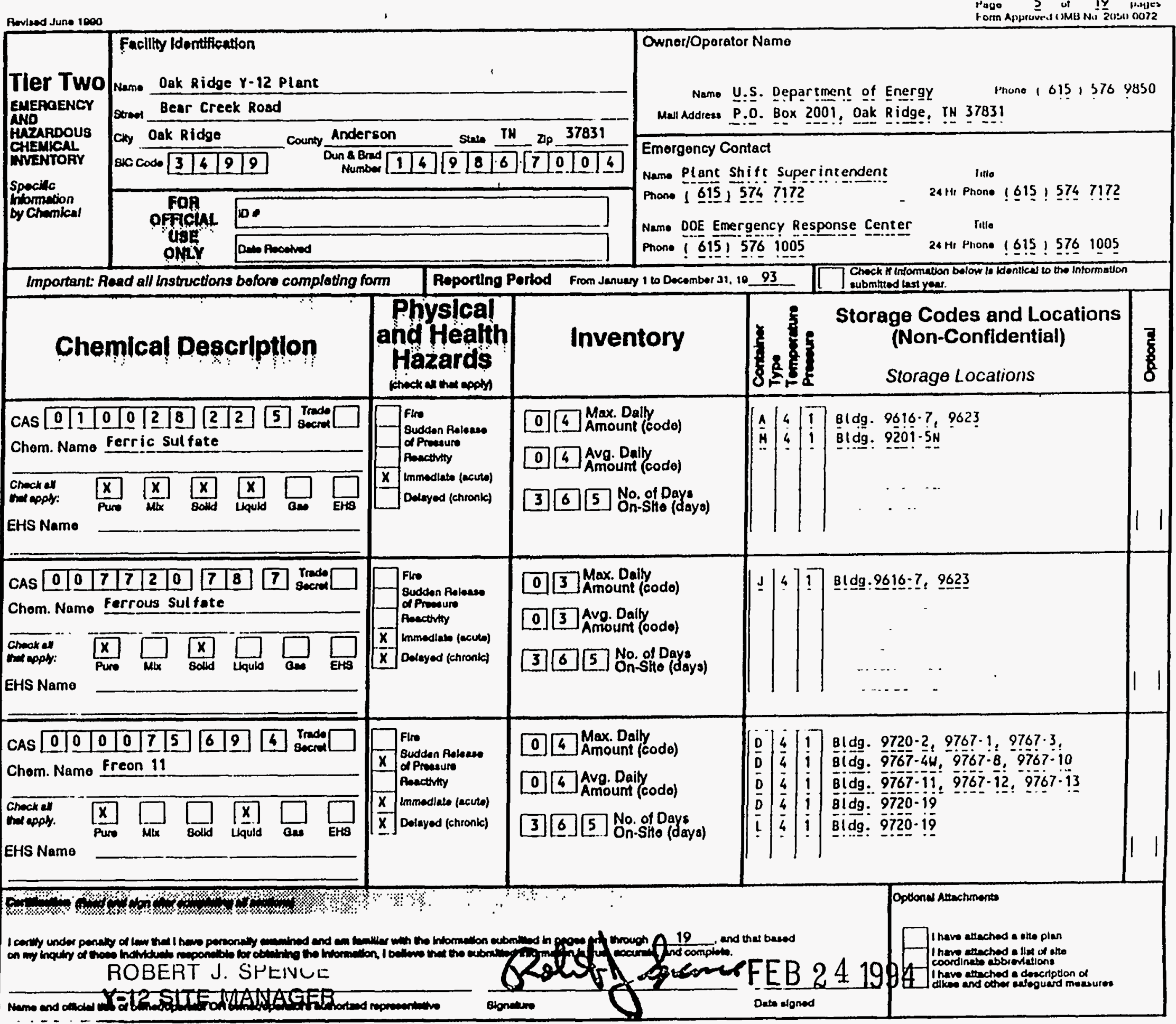




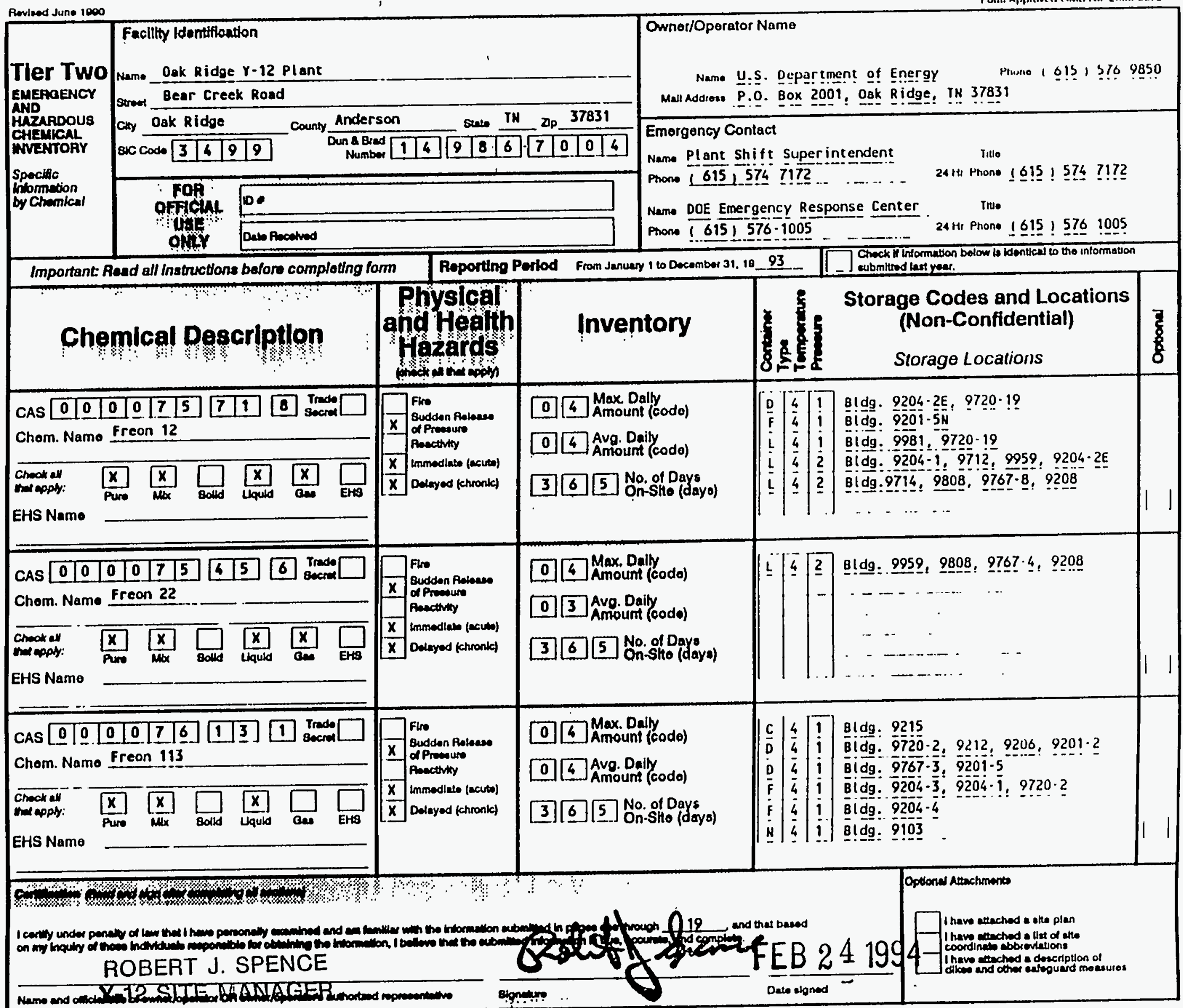




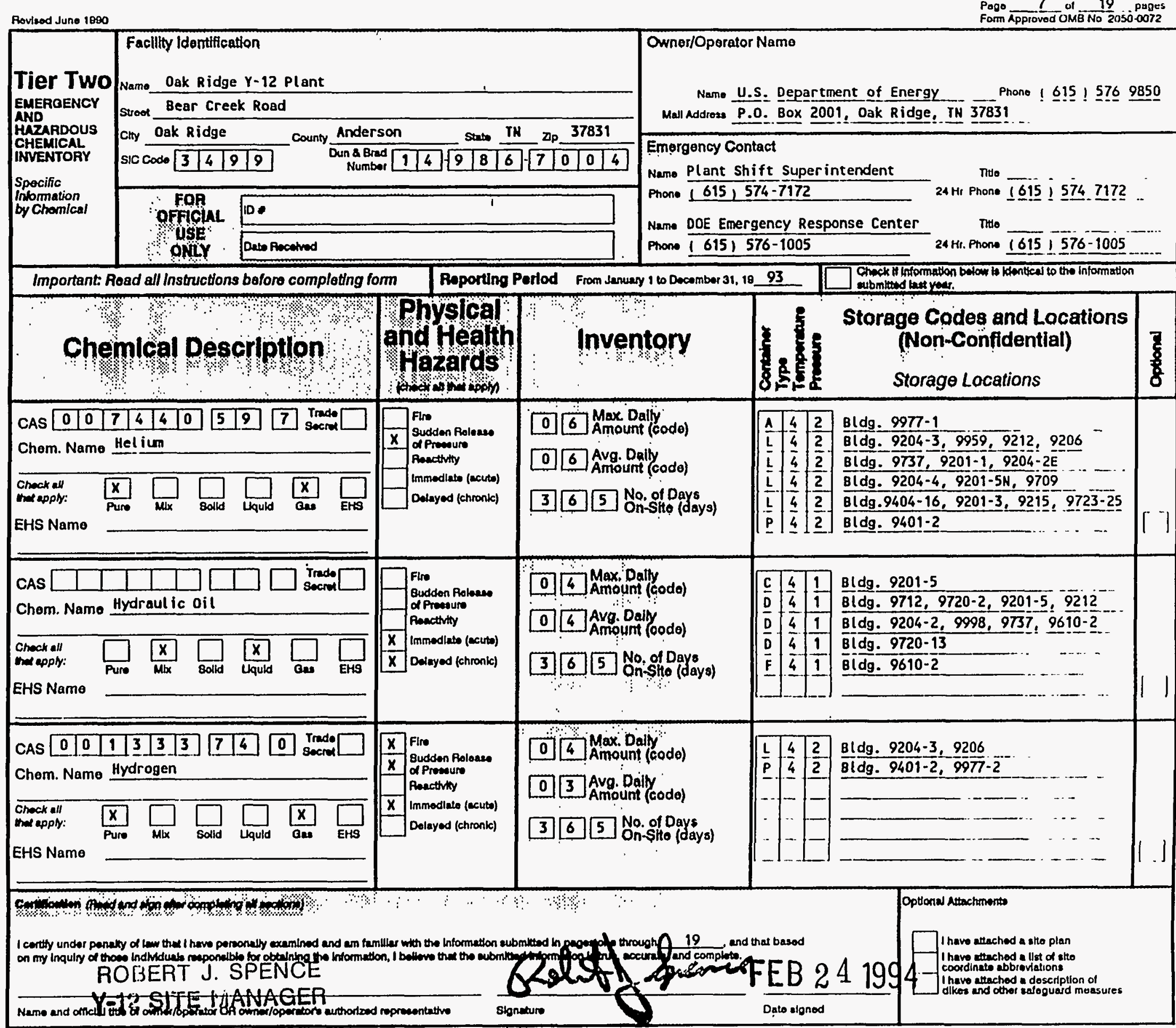




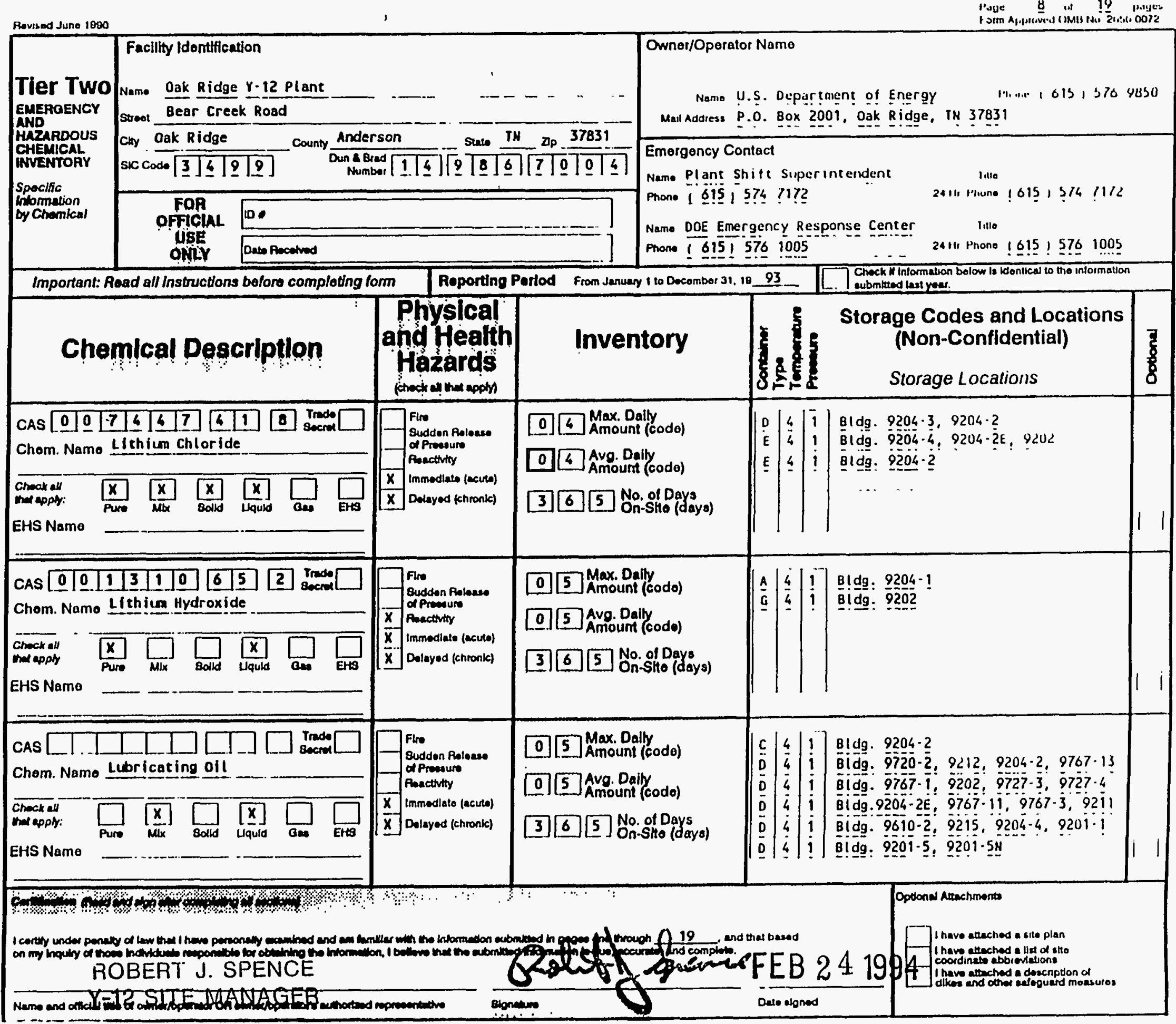




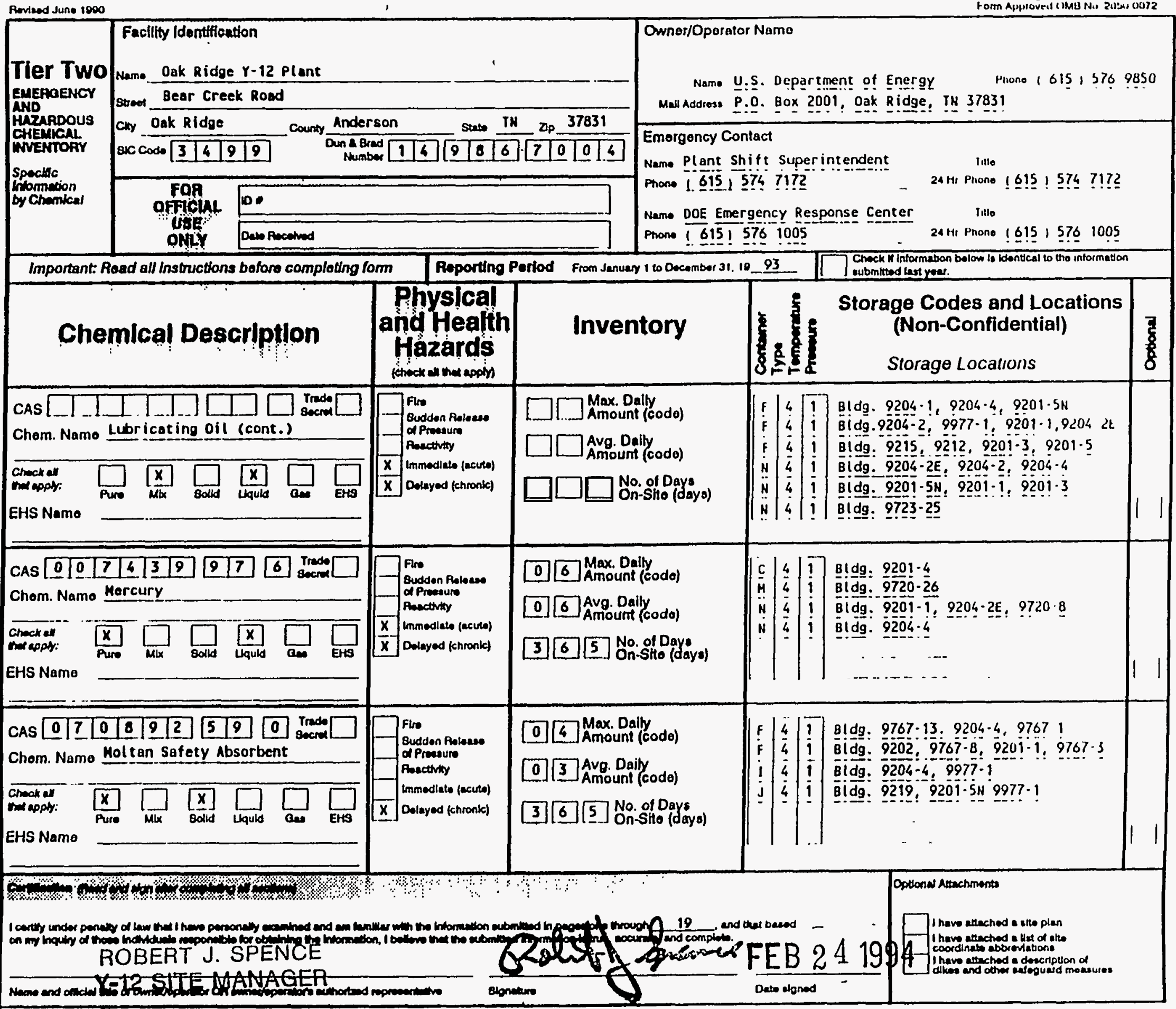



Emergency Contact

Name Plant Shift Superintendent

Phono $1.615,1.5747172$

itlie

Namo DOE Emergency Response Center litlo

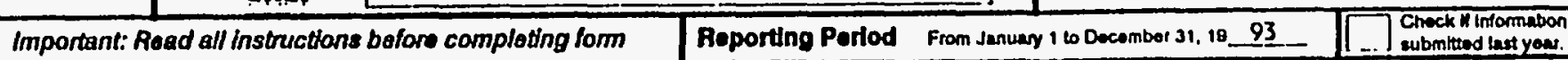

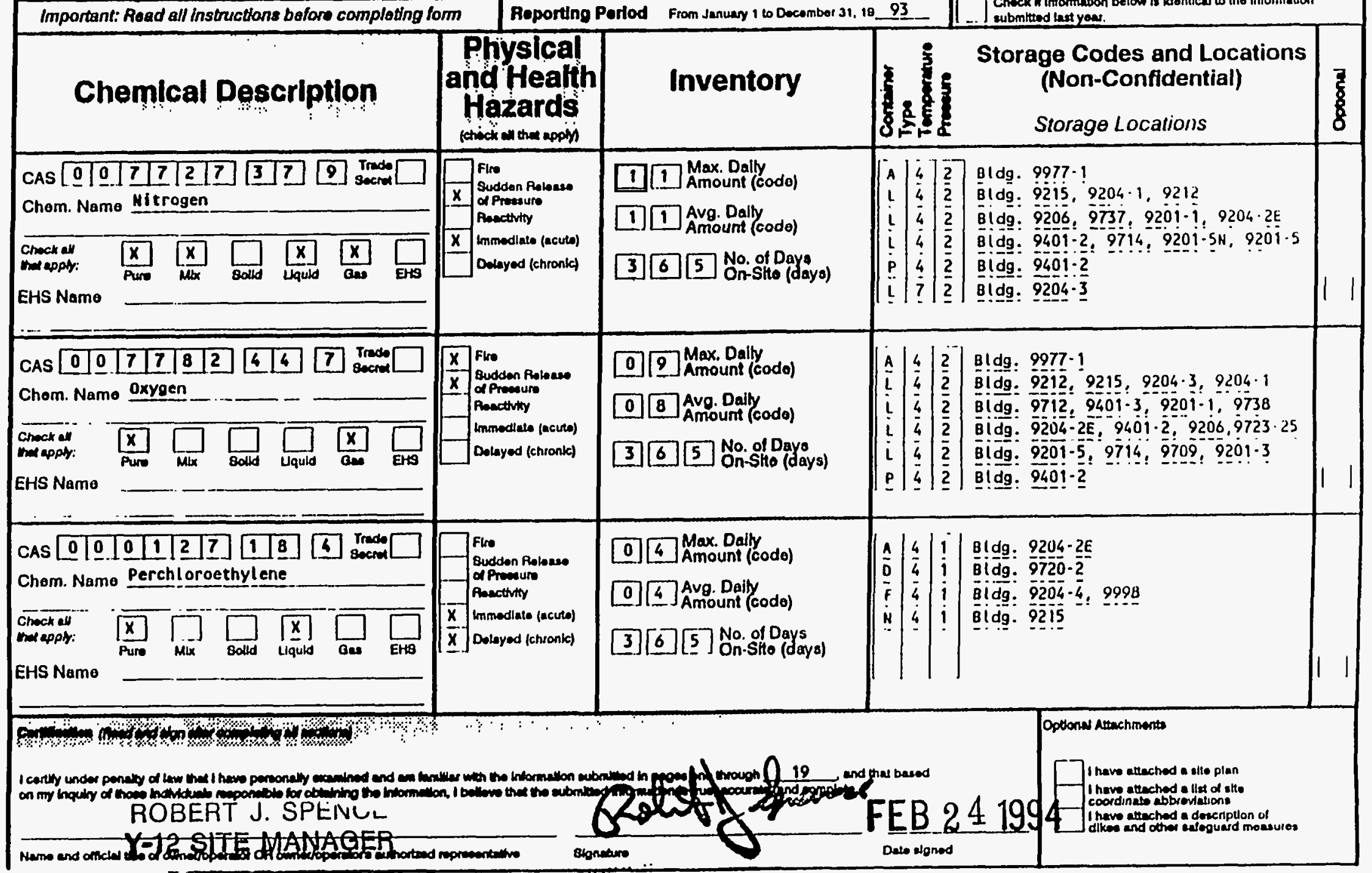




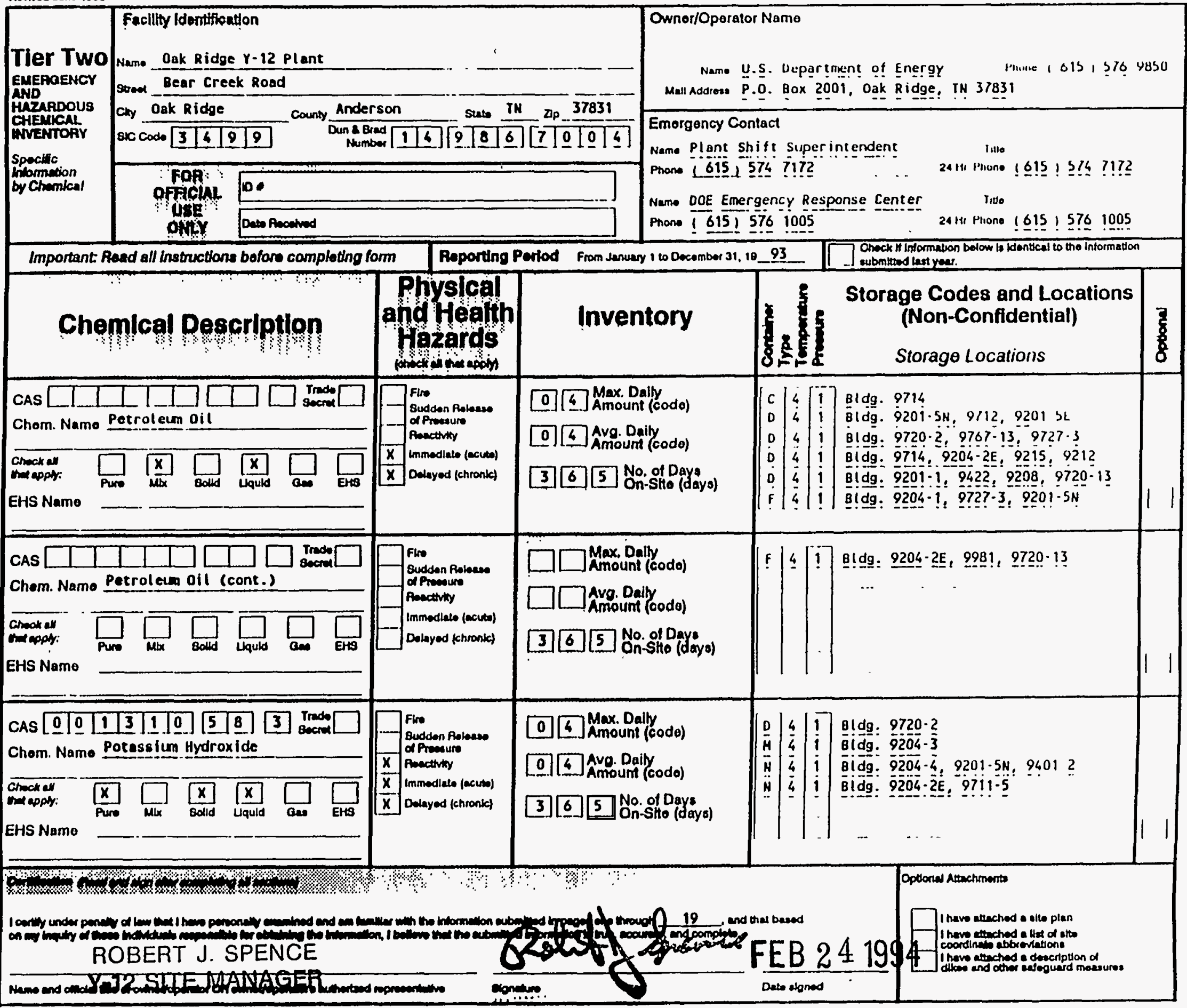




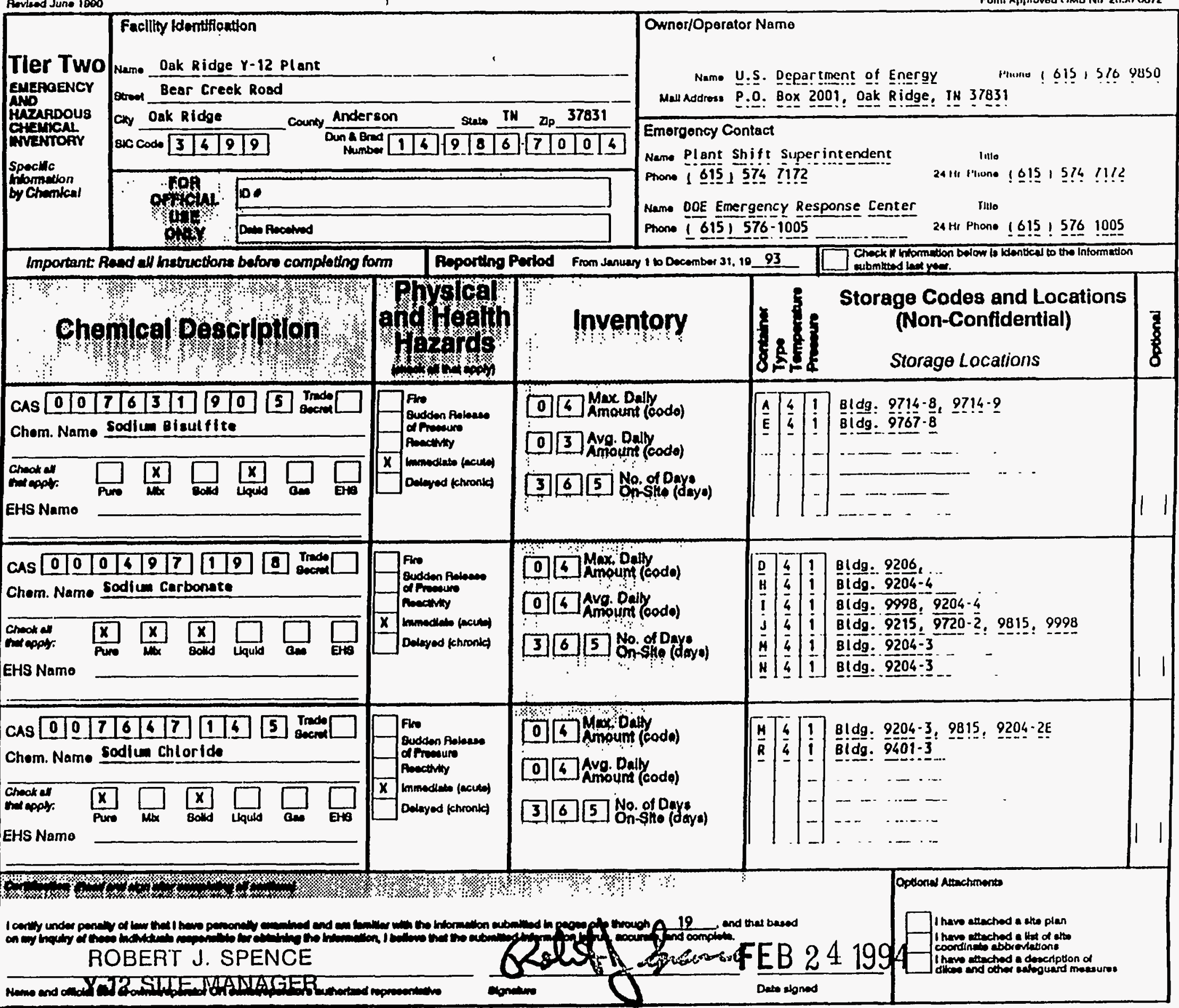




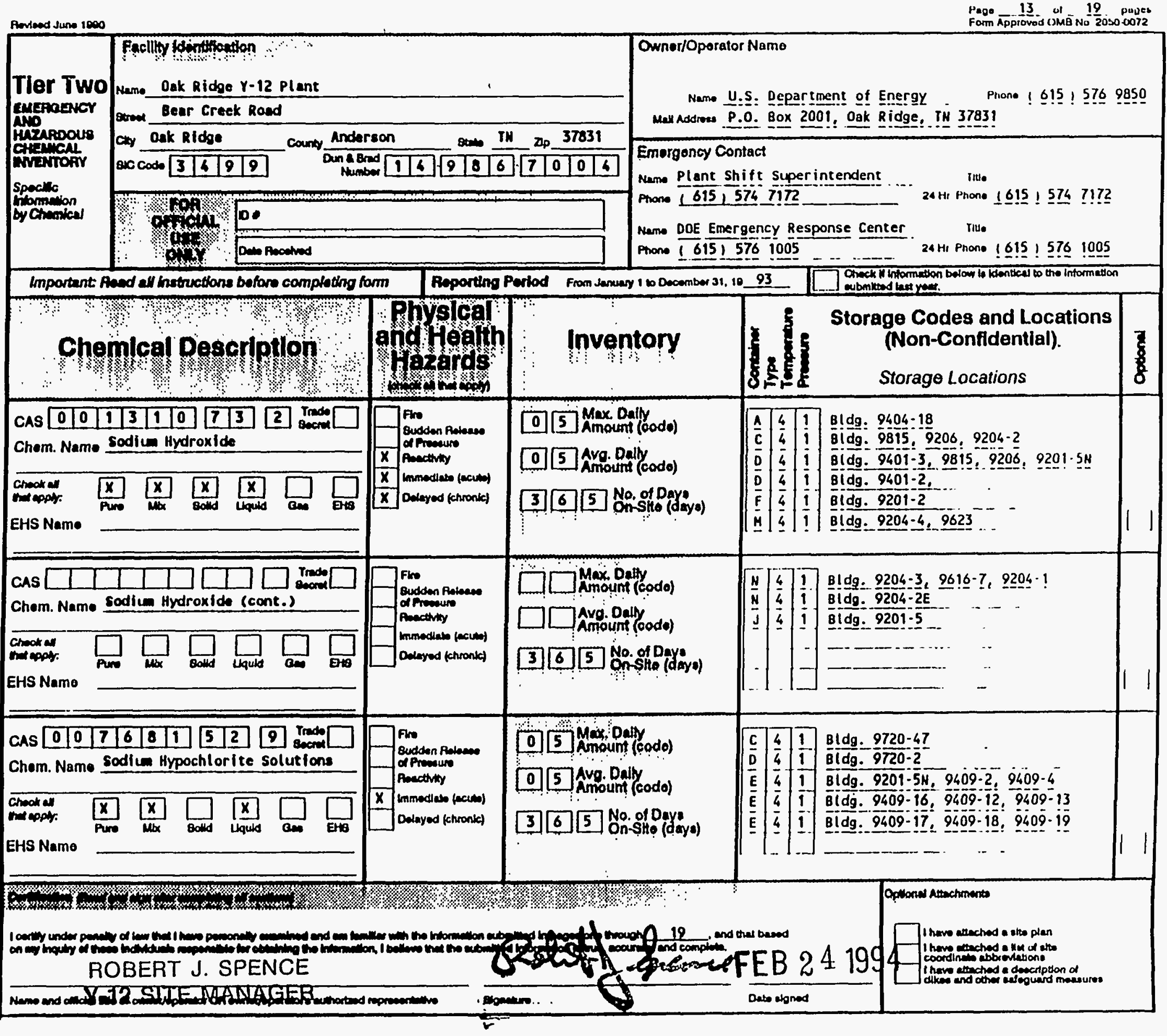




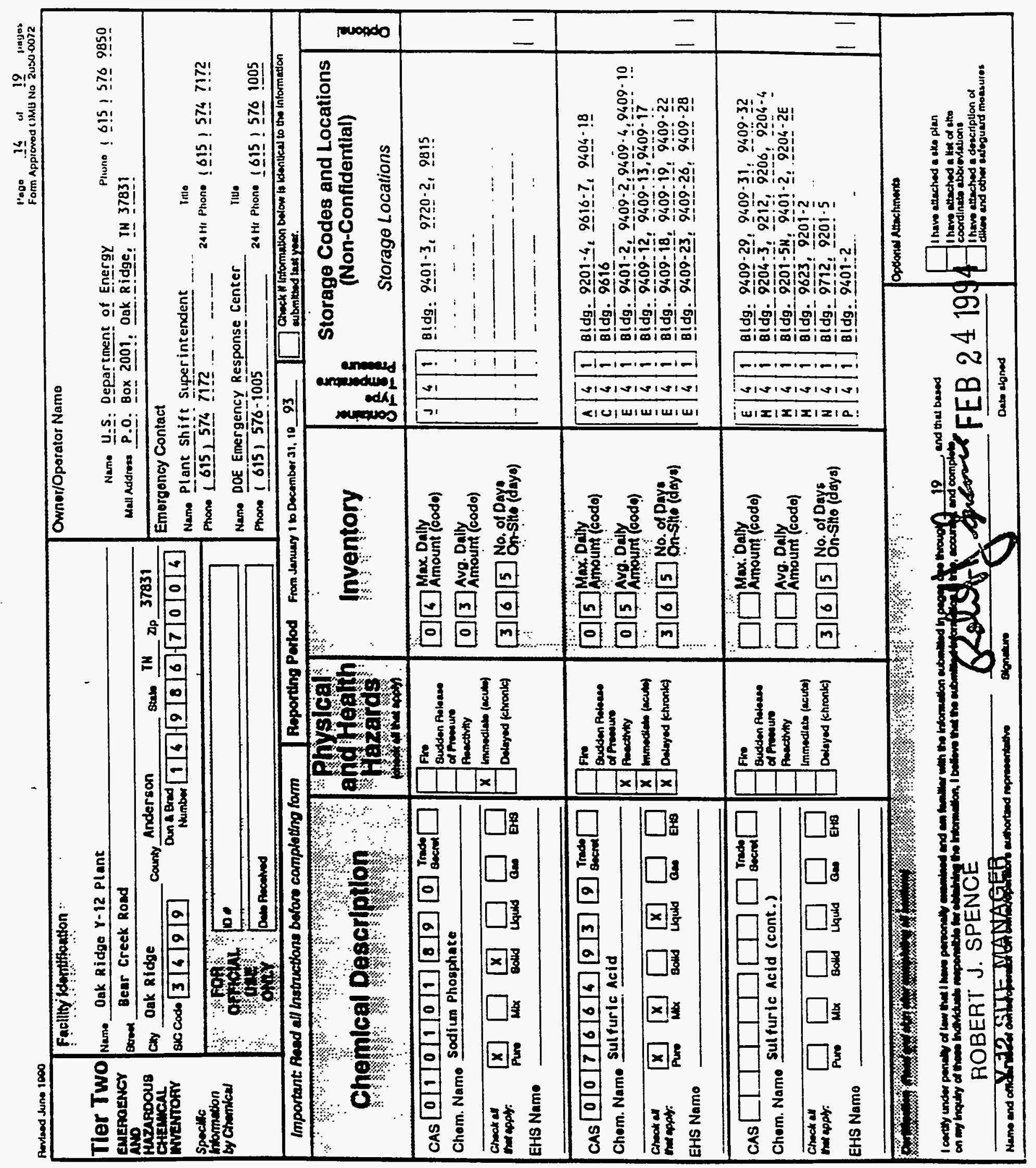




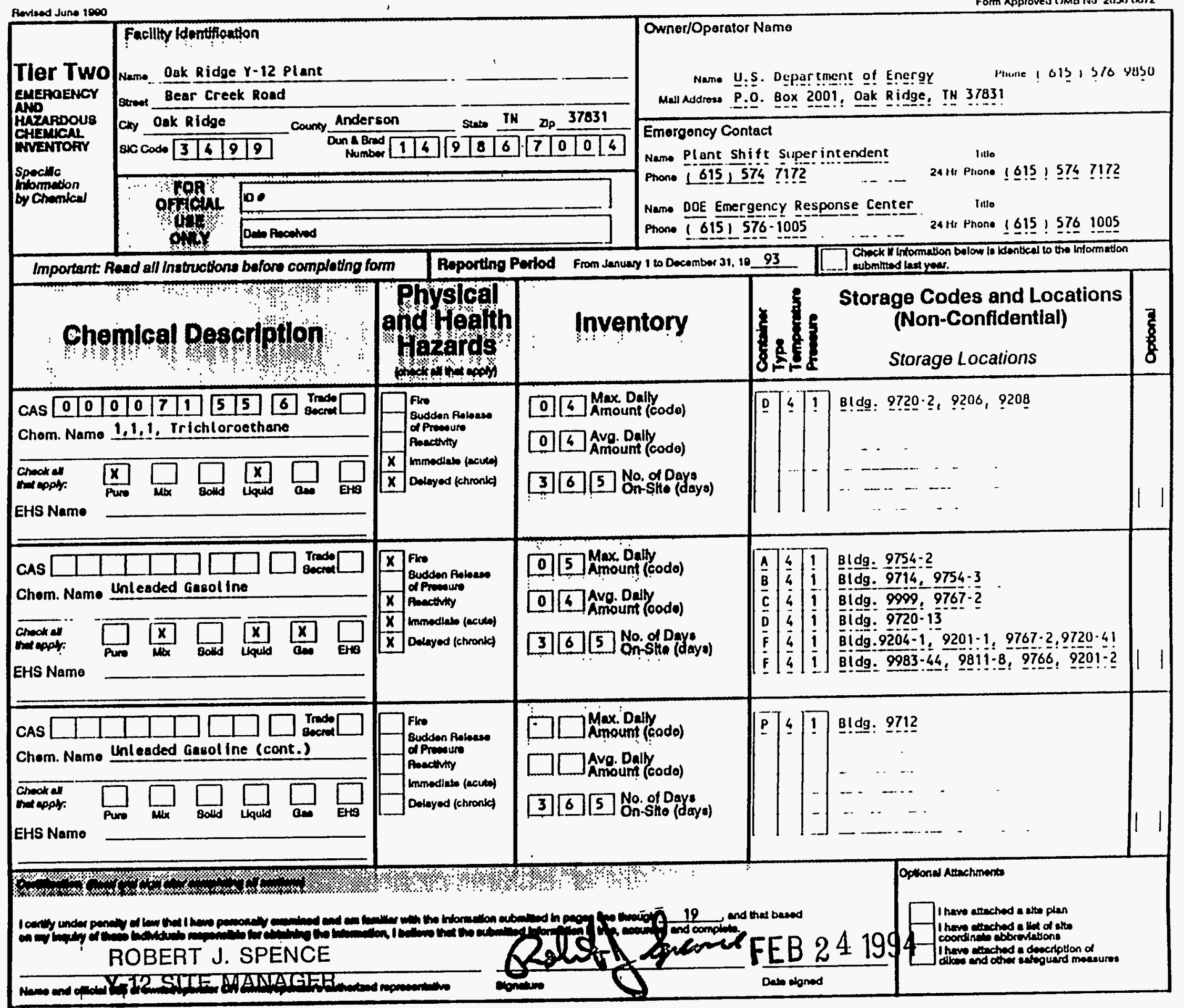




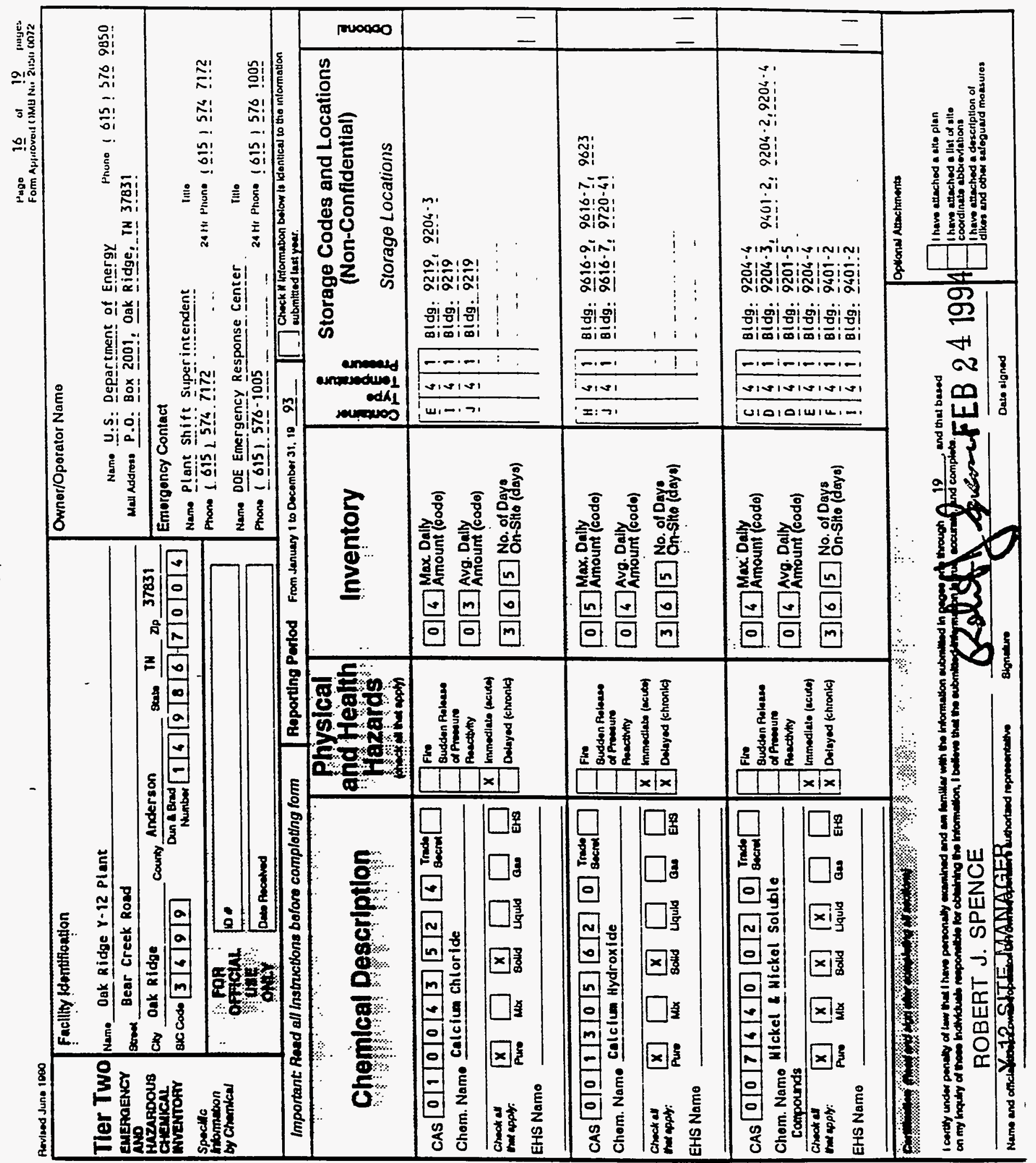




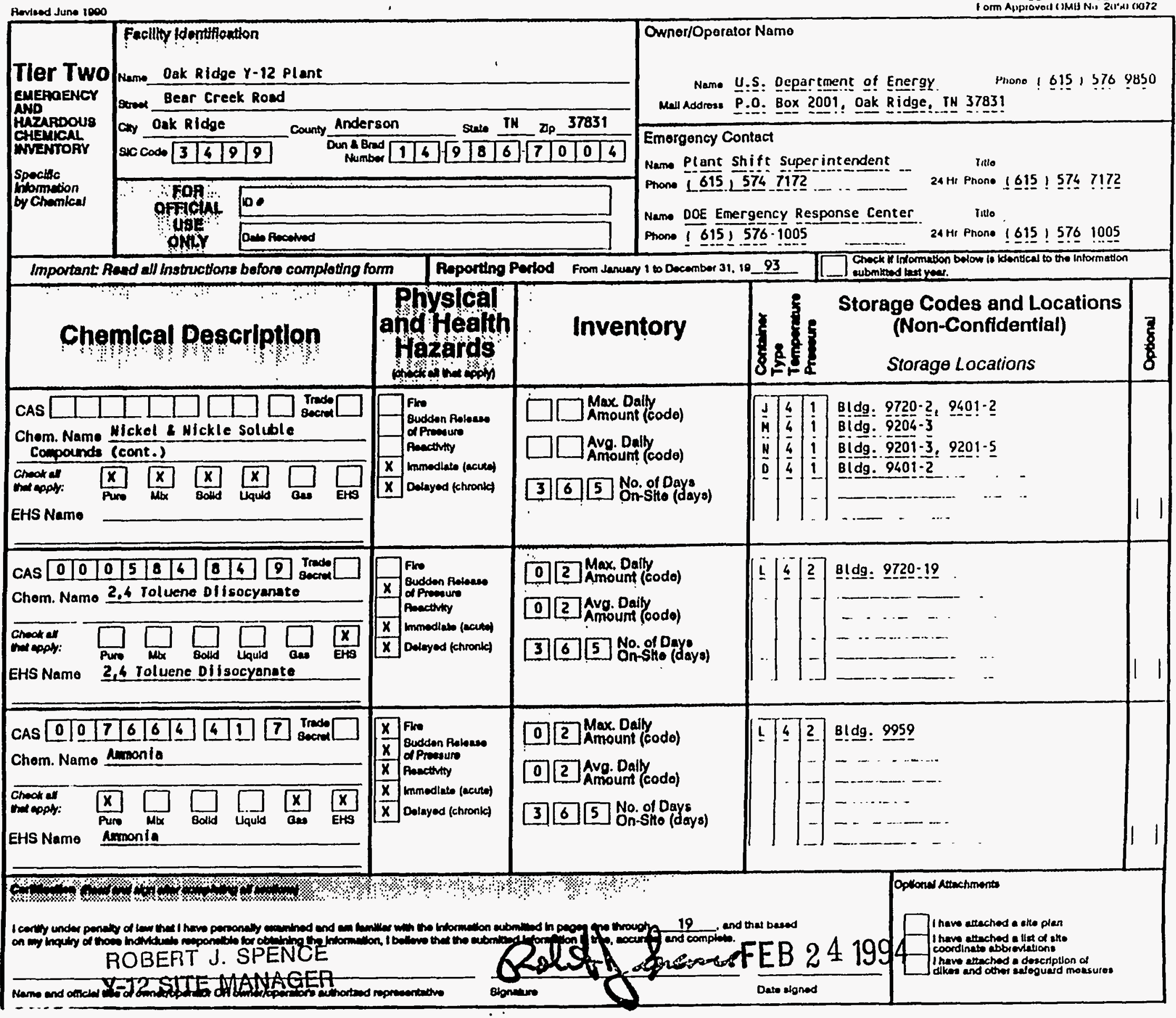




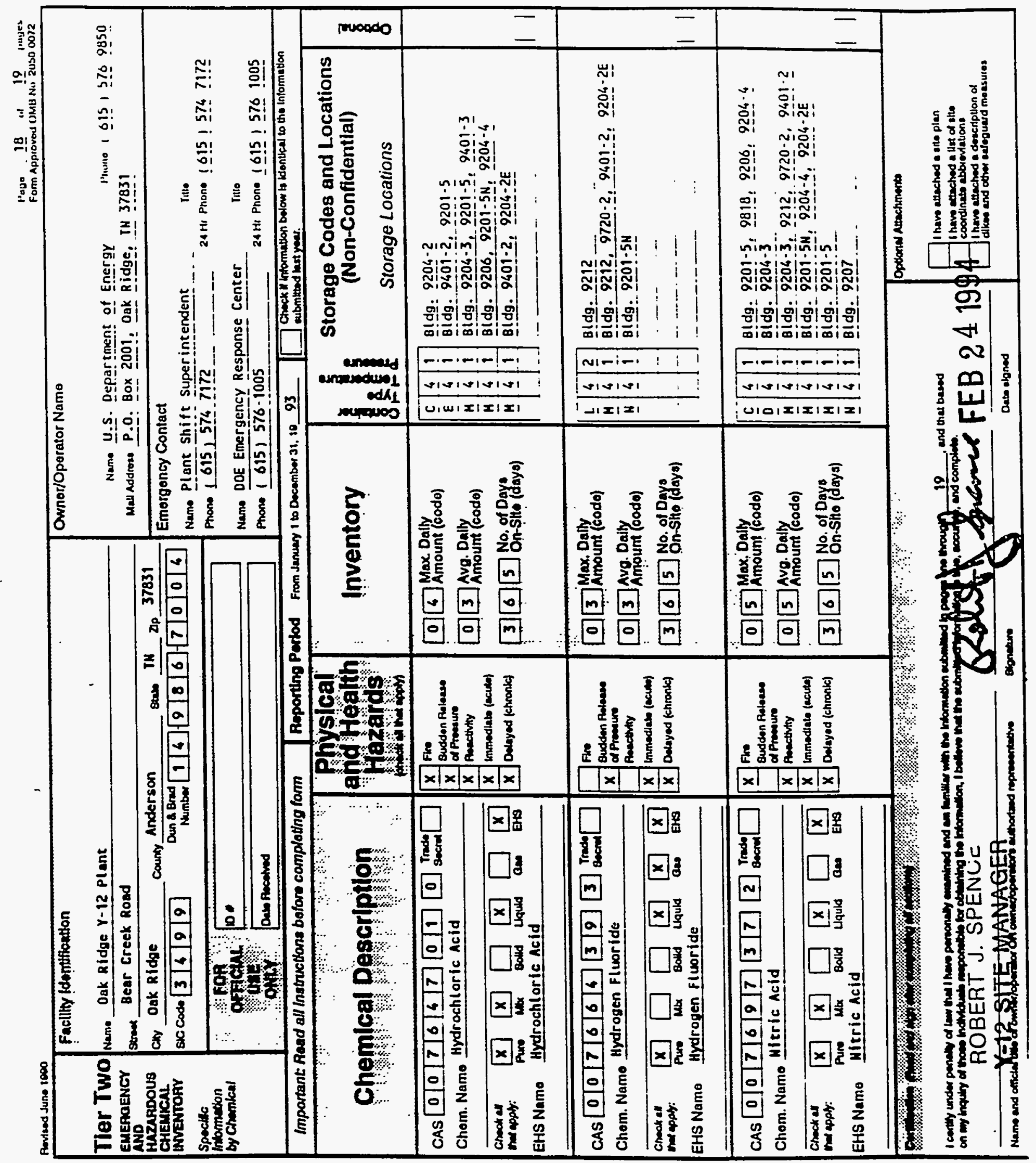




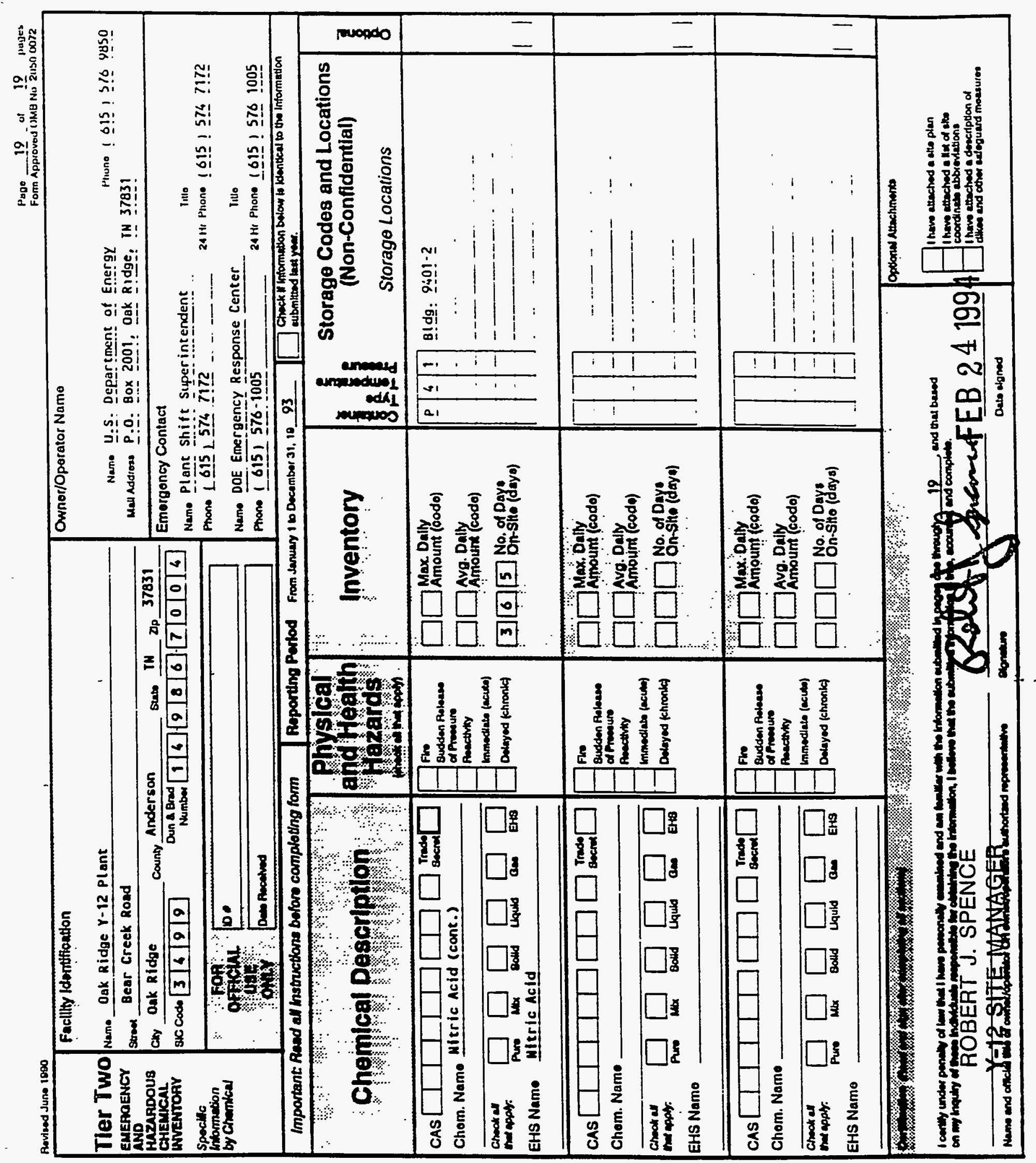


Distribution:

Recipients as designated by the author plus

A. K. Lee/DOE-OSTI, 9731, MS-8175 (2)

Y-12 Central Files, 9711-5, MS-8169 